\title{
Pertumbuhan Ideologi Pendidikan di Era Reformasi (Kajian terhadap Ideologi Pendidikan di Kuttab Al Fatih Purwokerto)
}

\author{
Fahri Hidayat \\ Institut Agama Islam Negeri Purwokerto \\ email: fahrisukses678@gmail.com
}

\begin{abstract}
The momentum of reform opened the space for the development of various schools of thought and ideology in the public sphere. This is evidenced by, among other things, the emergence of religious education institutions established on the basis of ideology. That is, the discourse on ideology not only develops in discourse space but has metamorphosed into a real movement in the social sphere. This paper examines the ideological orientation of kuttab Al Fatih Purwokerto, an elementary education institution that wishes to bring back the past to the future by taking the format and form of an educational institution from a source claimed to be the original source of early Islamic education.
\end{abstract}

Keyword: education ideology, kuttab al fatih, Islamic education

\begin{abstract}
Abstrak
Momentum reformasi membuka ruang berkembangnya berbagai macam aliran pemikiran dan ideologi di ruang publik. Hal ini dibuktikan dari, di antaranya, bermunculannya lembagalembaga pendidikan keagamaan yang didirikan atas dasar ideologi. Artinya, diskursus tentang ideologi tidak hanya berkembang dalam ruang wacana saja, namun telah bermetamorfosa menjadi sebuah gerakan nyata di ranah sosial. Makalah ini mengkaji tentang orientasi ideologi dari kuttab Al Fatih Purwokerto, sebuah lembaga pendidikan tingkat dasar yang ingin menghadirkan kembali masa lalu ke masa depan dengan mengambil format dan bentuk lembaga pendidikan dari sumber yang diklaim sebagai sumber asli pendidikan Islam masa awal.
\end{abstract}

Kata kunci: ideologi pendidikan, kuttab al fatih, pendidikan Islam

\section{PENDAHULUAN}

Paska reformasi, banyak bermunculan sekolah-sekolah yang menggunakan label Islam, seperti di antaranya Sekolah Islam Terpadu (SIT). Menurut Suyatno, munculnya sekolahsekolah Islam Terpadu merupakan respon atas ketidakpuasan terhadap Sistem Pendidikan Nasional. ${ }^{1}$ Embrio ideologi sekolah-sekolah

\footnotetext{
${ }^{1}$ Suyatno, "Sekolah Islam Terpadu: Gnealogi, Ideologi, dan Sistem Pendidikan”, (Yogyakarta, Disertasi UIN Sunan Kalijaga, 2013), hlm. 5-6.
}

baru tersebut tentu sudah ada jauh sebelum sekolah-sekolah tersebut lahir. Akan tetapi, momentum reformasi menjadi momentum untuk mengaktualisasi ideologi tersebut dalam bentuk gerakan yang dimanifestasikan dalam unit pendidikan.

Berkembangnya Lembaga-lembaga pendidikan Islam sejalan dengan proses islamisasi masyarakat Indonesia itu sendiri. Di luar pendidikan sekolah, ada beberapa lembaga pendidikan Islam non-sekolah yang 
juga berkembang, di antaranya adalah kuttab. Istilah kuttab memang terdengar masih asing bagi sebagian masyarakat. Kuttab merupakan sebuah lembaga pendidikan Islam yang ingin mengadopsi sistem pendidikan Islam yang ada pada masa nabi. Lembaga ini memiliki karakteristik yang berbeda lembaga pendidikan Islam lainnya seperti madrasah dan pesantren. Meskipun tergolong masih baru, namun ternyata respons masyarakat terhadap kuttab sangat positif. Hal ini dapat dilihat dari tingginya animo masyarakat untuk mendaftarkan anaknya di lembaga ini. Kuttab Al Fatih yang didirikan di kota Purwokerto pada tahun 2012 merupakan salah satu dari banyak kuttab yang dikembangkan di beberapa kota besar di Indonesia. Menurut wawancara dengan Fajar Pujiyanto, Kepala Kuttab Al Fatih Purwokerto², penerimaan santri baru di kuttab Al Fatih Purwokerto setiap tahunnya selalu melampaui target. Oleh karenanya, pihak kuttab harus melakukan seleksi terhadap calon santri.

Pada umumnya, lembaga-lembaga pendidikan Islam yang lahir paska reformasi dicirikan dengan kurikulumnya yang menyandingkan antara ilmu agama dengan ilmu pengetahuan umum. Demikian pula pada kuttab Al Fatih, slogan "melahirkan generasi emas pada usia belia" yang menjadi visi lembaga ini diturunkan ke dalam pengajarannya dengan menyandingkan ilmu umum dan agama. Hanya saja, istilah yang digunakan dalam kuttab adalah "pengokohan iman", karena ilmu umum hanya dijadikan sebagai tambahan informasi saja, sedangkan yang mendominasi pengajaran adalah pelajaran agama.

Menariknya, biaya pendidikan di kuttab Al Fatih ini tergolong tinggi ${ }^{3}$. Artinya, bisa dipahami

\footnotetext{
${ }^{2}$ Wawancara dengan Fajar Pujiyanto, SPd.I, kepala kuttab Al Fatih pada tanggal 7 Mei 2017.

${ }^{3}$ Wawancara dengan Fajar Pujianto, Kepala Kuttab Al Fatih Purwokerto pada tanggal 7 Mei 2017. Menurutnya, Kuttab Al Fatih menggunakan standar dinar dan dirham dalam hal pembiayaan pendidikan. Biaya pendaftaran adalah sebesar 3 dinar (sekitar 6 juta rupiah), sedangkan biaya perbulannya sebesar 6 dirham (sekitar 400 ribu rupiah). Meskipun demikian, transaksi tetap dilakukan dengan menggunakan mata uang rupiah.
}

bahwa orang tua yang mendaftarkan anaknya di lembaga ini berasal dari kelas menengah.

Berangkat dari latar belakang di atas, maka penulis tertarik untuk melakukan kajian secara akademik tentang ideologi pendidikan Islam di kuttab Al Fatih Purwokerto. Penelitian ini merupakan penelitian lapangan yang dikombinasikan dengan beberapa sumber literatur. Data lapangan didapatkan melalui wawancara, dokumentasi, dan observasi lapangan. Asumsi awalnya adalah lembaga ini merupakan "produk era reformasi" yang memiliki orientasi dan konstruksi ideologi yang berbeda dengan lembaga-lembaga pendidikan Islam lainnya. Penelitian ini akan menjawab apa dan bagaimana orientasi ideologi kuttab Al Fatih Purwokerto. Hasil dari penelitian ini diharapkan bermanfaat untuk memberikan informasi tentang dinamika pendidikan Islam pasca reformasi, terutama dalam hal perkembangan ideologinya.

\section{Reformasi dan Pendidikan Islam}

Lahirnya era reformasi yang membuka kran kebebasan memberikan implikasi pada banyak hal, termasuk pada perkembangan pendidikan Islam di Indonesia. Jika pada era sebelumnya kebebasan berpendapat benar-benar dibatasi untuk tidak mengatakan dibungkam-, pada era baru ini semua pemikiran, ide, dan gagasan yang tumbuh dan berkembang dari "arus bawah" menemukan momentum untuk berkembang di ruang publik. Berbagai macam organisasi masyarakat (ormas) bermunculan dengan membawa ide perjuangannya masing-masing. Ada yang didirikan atas dasar kepentingan kelompok yang bersifat pragmatis, ada pula yang dibangun di atas ideologi keagamaan. Dengan mengecualikan beberapa ormas keagamaan yang sudah ada sebelumnya dan sudah berusia matang, seperti Muhammadiyah dan Nahdhatul Ulama (NU), paska reformasi bermunculan berbagai macam ormas keagamaan lainnya dengan varian ideologinya masing-masing.

Dalam pandangan Yudi Latif, kemunculan orde reformasi membawa landmark baru dalam dunia politik di Indonesia, yaitu muncul sebuah gejala yang disebutnya sebagai "penghijauan" 
elite politik. ${ }^{4}$ Yudi meminjam klasifikasi Geertz untuk menyebut kelompok "muslim taat" sebagai kelompok santri. Menurutnya, kepemimpinan kenegaraan dan birokrasi paska reformasi memperlihatkan representasi kaum santri yang mencolok yang belum ada tandingannya di dalam sejarah Indonesia paska kolonial. Sebelumnya, eksistensi kaum santri sebagai entitas politik kurang mendapatkan tempat. Selama pemerintah orde baru, kiprah kaum santri di panggung politik selalu berada di kelas dua, dan dalam situasi-situasi tertentu sebenarnya hanya sekadar menjadi simbol belaka. Adapun, yang memegang otoritas secara dominan adalah kelompok yang oleh Geertz disebut sebagai kelompok priyayi.

Sejak masa kolonial, kaum santri memiliki peran yang sangat penting dalam dinamika sosial-politik di nusantara. sejarah mencatat fakta bahwa kemunculan gerakan-gerakan di tanah air banyak didorong oleh semangat keagamaan. Gerakan-gerakan yang bermunculan pada awal abad 19 membuktikan hal itu. Sarikat Dagang Islam (SDI) yang kemudian bermetamorfosa menjadi Sarikat Islam (1912) dan Jami`at Khair (1901) adalah dua organisasi yang tercatat kemunculannya paling awal. Dari simbolisasi pada penamaannya saja, dapat diketahui bahwa organisasi tersebut merupakan ormas keagamaan. Peran ormas keagamaan dalam upaya kemerdekaan juga tidak dapat dipandang sebelah mata. Muhammadiyah (1912), misalnya, yang pada saat kemunculannya di Kauman Yogyakarta mampu meraih banyak pengikut dari kalangan Muslim perkotaan mengambil bagian penting dalam proses pendidikan masyarakat. Organisasi yang didirikan oleh Ahmad Dahlan ini mengambil metode pendidikan dari Barat untuk diimplementasikan dalam pengembangan pendidikan Islam.

NU yang lahir beberapa tahun kemudian (1926) juga turut mengambil bagian penting dalam mendidik anak bangsa. Organisasi yang

\footnotetext{
${ }^{4}$ Yudi Latif, Dialektika Islam: Tafsir Sosiologis atas Sekularisasi dan Islamisasi di Indonesia, (Yogyakarta: Jalansutra, 2007), hlm. 2.
}

dinakhkodai oleh Hasyim Asy`arie dengan pendidikan pesantren-nya ini melanjutkan estafet perjuangan Muhammadiyah dengan membidik segmentasi yang berbeda, yaitu masyarakat muslim tradisional. Yang menarik, beberapa ormas seperti Muhammadiyah, NU dan Persis, didirikan seusai para pendirinya pulang dari tanah suci untuk melaksanakan ibadah haji. Pada saat itu kota Mekah menjadi pusat berkumpulnya para ulama dan intelektual Muslim se-dunia untuk berdiskusi tentang tematema kemerdekaan dan kebangkitan Islam. Dengan mempertimbangkan hal tersebut, maka hipotesa yang mengatakan bahwa asal-usul pemikiran (gnealogi) pemikiran para tokoh pendiri ormas-ormas besar di Indonesia lahir dari gerakan intelektual di timur tengah bisa dipahami.

Melihat begitu dominannya peran kaum santri pada rentang panjang periode sejarah Indonesia, maka tidak mengherankan jika terjadi semacam "efek pegas" ketika mereka mendapatkan tekanan politik dari penguasa. Kaum santri yang ditekan pada masa pemerintahan Orde baru bangkit kembali dengan gaung yang lebih keras pada era reformasi. Kebijakan pemerintah orde baru yang hanya mengizinkan dua partai politik dan satu golongan karya sebagai wadah politik memaksa seluruh kelompok Islam yang sesungguhnya memiliki ideologi yang berbeda-beda untuk bergandengan tangan berada di bawah satu bendera Partai Persatuan Pembangunan (PPP). Varian pemikiran keagamaan pada masa ini memang tidak tampak di permukaan. Meskipun begitu, perbedaan-perbedaan dalam pemikiran keagamaan telah ada dan secara diam-diam bergeliat menjadi arus kuat di akar rumput yang pada gilirannya nanti kelompok-kelompok ini menggunakan momentum reformasi untuk menampakkan eksistensinya.

Noorhaidi Hasan menyatakan bahwa ledakan Islam di arena politik pasca-Orde baru mendapatkan perhatian dari banyak pengamat dalam maupun luar negeri. ${ }^{5}$ Istilah "ledakan"

${ }^{5}$ Noorhaidi Hasan, Laskar Jihad: Islam, Militansi, 
yang oleh Noorhaidi dilekatkan pada gerakan Islam ini tampaknya menggambarkan situasi paska tumbangnya Orde baru momentum reformasi benar-benar menjadi ajang bagi kelompok-kelompok Islam yang sebelumnya hanya bergerak di ruang gelap "bawah tanah" untuk membuka diri di ruang publik dan mendeklarasikan eksistensinya. Di antara ormas keagamaan yang secara de jure lahir pasca reformasi adalah Majelis Mujahidin Indonesia (MMI), Hizbut Tahrir Indonesia (HTI), Kesatuan Aksi Mahasiswa Muslim Indonesia (KAMMI), Front Pembela Islam (FPI), dan lain sebagainya. Ormas-ormas tersebut, meskipun sama-sama terdorong oleh semangat agama, namun bermunculan dengan membawa bendera dan ideologi yang berbedabeda. Di samping ormas-ormas di atas, terdapat juga beberapa kelompok non-ormas, seperti kelompok salafi yang juga memiliki orientasi ideologi yang khas.

Pemilihan umum (pemilu) legislatif tahun 1999 menegaskan fakta tersebut. Pemilu pertama pada era reformasi tersebut diikuti oleh 48 partai politik. Jumlah ini merupakan jumlah keikutsertaan partai politik (parpol) terbesar dalam sejarah politik Republik Indonesia. Di antara 48 parpol tersebut, terdapat 15 parpol yang menyatakan diri sebagai parpol Islam atau berbasis masa Islam. Selain itu, terdapat pula beberapa parpol berbasis agama non-Islam. Tingginya partisipasi parpol pada pemilu ini menggambarkan kompleksitas masyarakat Indonesia yang sesungguhnya. Masyarakat Indonesia, khususnya masyarakat muslim, memiliki orientasi ideologi yang beragam, yang oleh karenanya membutuhkan wadah aspirasi yang juga berbeda-beda.

Di antara 15 parpol Islam tersebut, ada beberapa yang berafilisasi pada ormas yang sudah ada sebelumnya. Seperti, Partai Kebangkitan Bangsa (PKB) yang merupakan under bow Pengurus Besar Nahdhatul Ulama (PBNU) dan Partai Amanat Nasional (PAN)

dan Pencarian Identitas di Indonesia Pasca- Orde Baru, (Jakarta: LP3ES, 2008), hlm. 3. yang meskipun tidak memiliki keterkaitan struktural dengan Muhammadiyah, namun basis konstituen terbesarnya adalah warga Muhammadiyah. Ada juga beberapa parpol yang mengusung simbol-simbol romantik, seperti Partai Masyumi Baru, yang dari aspek penamaannya tampak ingin mengingatkan konstituen muslim tentang kejayaan Masyumi pada masa lalu. Selain itu, ada pula parpol yang "mengimpor" ideologi dari luar, seperti Partai Keadilan (belakangan menjadi Partai Keadilan Sejahtera), yang merupakan metamorfosa politik dari jamaah tarbiyah. Kelompok ini mengambil inspirasi ideologi dari gerakan Ikhwanul Muslimin yang ada di Mesir.

Era reformasi yang mengakomodasi perbedaan-perbedaan di ruang publik dapat menggambarkan identitas masyarakat muslim Indonesia yang sebenarnya. Bukan identitas yang dibentuk dan dipaksakan oleh penguasa. Bahkan, perubahan-perubahan sosial dalam Islam lebih banyak berasal dari bawah ketimbang dari atas. ${ }^{6}$ Pasca reformasi, masyarakat Muslim Indonesia bergerak menjadi semakin religius. Proses islamisasi dari akar rumput terjadi. Hal ini dapat dilihat, salah satunya, dari trend memakai jilbab yang berkembang signifikan ketimbang periode sebelumnya. Hari ini, jilbab merupakan pakaian yang sangat biasa dipakai oleh wanita muslimah, baik di sekolah, di pasar, ataupun di instansi-instansi pemerintah. Fenomena ini tentu kontras dengan pada zaman Orde baru, dimana dulu jilbab dilarang oleh pemerintah karena merupakan simbol agama.

\section{Ideologi sebagai Core Value Pendidikan}

Ideologi adalah suatu konstruksi pemahaman tentang sesuatu. Ideologi dikatakan sebagai sistem ide-ide tentang fenomena, terutama fenomena kehidupan sosial. Ideologi merupakan cara berpikir yang khas oleh suatu kelompok atau individu. Dalam konteks pendidikan Islam, cara pandang terhadap sebuah fenomena terkadang dipengaruhi oleh tipologi pemikiran keagamaan yang lebih luas.

\footnotetext{
${ }^{6}$ Yudi Latif, Dialektika Islam,... hlm. 48.
} 
Konsep ulama, misalnya, diterjemahkan secara beragam. Ada beberapa aliran dalam pemikiran Islam yang membatasi definisi ulama pada orang-orang tertentu yang dianggap ahli dalam bidang keagamaan. Aliran lain mengatakan bahwa konsep ulama dalam terminologi AlQur'an bersifat umum dan tidak membatasi pada bidang keagamaan saja. Ada juga yang justru memperluas definisi agama itu sendiri menjadi bukan sekadar aspek-aspek yang berhubungan dengan kehidupan akhirat, namun mencangkup semua dimensi kehidupan. Bisa dikatakan, ideologi pendidikan Islam merupakan cara pandang suatu kelompok keagamaan tentang tema-tema pendidikan.

Menurut Alastair C. Maclntyre, sebagaimana dikutip oleh William F. O'neil, ideologi memiliki beberapa tampilan kunci. Pertama, ideologi berupaya untuk menggambarkan karakteristik-karakteristik umum tertentu alam, atau masyarakat, atau kedua-duanya. Kedua, ideologi meniscayakan adanya perhitungan tentang hubungan antara apa yang dilakukan dengan apa yang seharusnya dilakukan, yaitu keterkaitan antara hakikat dunia dengan hakikat moral, politik, dan panduan perilaku lainnya. Ketiga, ideologi tidak hanya dipercaya oleh anggota-anggota kelompok tertentu, melainkan diyakini sedemikian rupa sehingga ia setidak-tidaknya merumuskan sebagai keberadaan (eksistensi) sosial bagi mereka. ${ }^{7}$ Ideologi berbeda dengan madzhab keagamaan. Madzhab keagamaan adalah panduan praktis terhadap hukumhukum yang digali dari kitab suci. Sedangkan, ideologi merupakan cara pandang terhadap suatu fenomena. Ideologi berada pada ranah pemikiran seseorang. Biasanya, ideologi seseorang, atau sebuah kelompok, dapat diindentifikasi dengan membaca pandanganpandangannya terhadap beberapa tema, seperti politik dan pendidikan, muncul istilah ideologi politik, ideologi pendidikan, dan seterusnya.

${ }^{7}$ William F O`neil, Ideologi-ideologi Pendidikan, (Yogyakarta: Pustaka Pelajar, 2008), hlm. 32.
Sejalan dengan itu, Riberu menyatakan bahwa ideologi dapat diturunkan ke dalam beberapa unsur, yaitu: 1) pandangan yang komprehensif tentang manusia, dunia, dan alam semesta dalam kehidupan. 2) rencana penataan sosial-politik berdasarkan paham tersebut, 3) kesadaran dan pencanangan dalam bentuk perjuangan melakukan perubahanperubahan berdasarkan paham dan rencana ideologi tersebut, 4) usaha mengarahkan masyarakat untuk menerima ideologi tersebut yang menuntut loyalitas masyarakat untuk menerima ideologi tersebut yang menuntut loyalitas dan keterlibatan para pengikutnya. 5) usaha memobilisasi seluas mungkin para kader dan massa yang akan menjadi pendukung ideologi tersebut. ${ }^{8}$ Oleh karenanya, memahami perilaku sebuah kelompok harus dimulai dari memahami bagaimana pandangan-pandangan (ideologi) kelompok tersebut terhadap sebuah fenomena. Sebab, pikiran dan tindakan adalah sesuatu yang saling mengisi. Pikiran seseorang akan menentukan tindakan-tindakannya.

Ideologi merupakan semacam guide line bagi sebuah sekolah untuk kemudian diterjemahkan menjadi aksi dalam sebuah perilaku. Melalui ideologi berlangsung suatu pemberian makna, yaitu pada saat makna atau ide mempengaruhi konsepsi aktivitas individu maupun kelompok yang membentuk dunia sosial. Secara umum, O'neil membagi ideologi pendidikan menjadi dua kategori besar, yaitu konservatif dan liberal. Namun, dua ideologi tersebut masih dipetakan lagi sehingga menjadi 6. Berikut penjelasan secara lebih rinci:

\section{Ideologi konservatif}

Menurut O'neil, akar dari ideologi pendidikan konservatif dibangun berdasarkan keyakinan bahwa masyarakat pada dasarnya tidak bisa merencanakan perubahan atau mempengaruhi kehidupan sosial. Aliran ini meyakini bahwa hanya Tuhan yang merencakan

${ }^{8}$ Riberu, dk, "Menguak Mitos-mitos Pembangunan: Telaah Etis dan Kritis" dalam Suyatno, "Sekolah Islam Terpadu, hlm. 39 . 
keadaan masyarakat dan hanya Tuhan yang mengetahui di balik itu semua. O'neil membagi ideologi ini menjadi tiga aliran.

Pertama, aliran fundamentalisme pendidikan. Aliran ini, menurut O'neil mendasarkan konsep etika pada apa yang telah diwahyukan di dalam kitab suci. Ada dua corak dasar fundamentalisme pendidikan, yaitu fundamentalisme sekuler dan fundamentalisme religius. Yang sekuler tidak memiliki kepastian-kepastian religius dan cenderung untuk mendasarkan posisinya pada prakiraanprakiraan yang kurang lebih bersifat intuitif atau akal sehat. Sedangkan, yang religius meyakini bahwa tujuan puncak pendidikan adalah untuk mematuhi kehendak Tuhan sebagaimana diwahyukan di dalam kitab suci agama-agama. ${ }^{9}$

Kedua, aliran intelektual pendidikan. Aliran ini mendasarkan diri pada pertimbanganpertimbangan tertentu pada wilayah filosofi dan moral yang didasarkan pada penalaran. Menurut O'neil, umumnya, inteletualisme pendidikan dilandasi oleh tiga prakiraan filosofis, yaitu; 1) bahwa dunia ini penuh dengan makna dalam dirinya. 2) Manusia tidak dilahirkan dalam keadaan memiliki pengetahuan tentang kebenarankebenaran, dan 3) hampir semua persoalan tentang kebenaran-kebenaran dapat dicapai dan dipahami lewat penalaran, kecuali pada beberapa kasus tertentu yang jumlahnya tidak banyak.

Sasaran-sararan yang hendak dicapai dalam aliran ini adalah setidaknya ada dua, yaitu mengajarkan siswa tentang bagaimana cara menalar, dan menyalurkan kebijaksanaan (hasil penalaran) yang bersifat tahan lama dari masa silam. Di antara ciri dari aliran ini adalah penekanannya pada nilai-nilai intelektualisme tradisional, yakni pemupukan nalar serta penelusuran kebijaksanaan spekulatif. Dalam ranah praksis, aliran ini memandang bahwa setiap wewenang dari seorang guru dalam suatu proses pembelajaran harus dapat diterima dan dibenarkan secara nalar. ${ }^{10}$

${ }^{9}$ William F O`neil, Ideologi-ideologi, hlm. 187247.

${ }^{10}$ Ibid., hlm. 260-287.
Ketiga, konservatisme pendidikan. Menurut O'neil, filosofi politik dari konservatisme pendidikan adalah posisi yang mengembangkan ketaatan terhadap lembagalembaga serta proses-proses budaya yang telah teruji oleh waktu, diiringi dengan rasa hormat yang mendalam terhadap hukum dan tatanan sebagai landasan dari setiap perubahan sosial. Aliran ini cenderung mengambil sikap skeptis terhadap teori murni dan spekulasi intelektual yang mengalir bebas. Bagi kaum yang menganut aliran ini, tujuan dan sasaran pendidikan adalah sebagai pelestarian dan penerusan pola-pola kemapanan sosial serta tradisi-tradisi. O'neil masih membagi lagi tipologi aliran ini menjadi beberapa sub-aliran, seperti konservatisme sekuler dan konservatisme pendidikan religius. ${ }^{11}$

\section{Ideologi Liberal}

Ciri utama dalam ideologi liberal adalah mendasarkan landasan pendidikannya pada prinsip-prinsip liberal. Di antaranya adalah pandangan bahwa seluruh pengetahuan merupakan hasil dari pengalaman personal (empirisme), sedangkan pengalaman personal merupakan perilaku timbal-balik antara makhluk dengan lingkungan fisik dan sosialnya. Ideologi ini menganggap bahwa semua perilaku tumbuh dari dalam hubungan timbal balik antara objek-objek dan peristiwa-peristiwa fisik. Selain itu, ideologi ini menganggap bahwa cara terbaik untuk berpikir adalah dengan menyelesaikan proses pemecahan masalah yang alamiah melalui serangkaian metode dan prosedur ilmiah pula. O'neil membagi ideologi ini menjadi tiga sub-ideologi (aliran), yaitu liberalisme pendidikan, liberasionisme pendidikan, dan anarkisme pendidikan.

Pertama, liberalisme pendidikan. Aliran ini menekankan bahwa sasaran puncak pendidikan haruslah berupa penanaman pembangunan kembali masyarakat mengikuti alur yang benarbenar berkemanusiaan (humanistik), menekankan perkembangan sepenuhnya dari potensi-potensi khas setiap orang sebagai makhluk manusia.

\footnotetext{
${ }^{11}$ Ibid., hlm. 295-333.
} 
Ini hanya bisa berlangsung di dalam kerangka kerja sebuah sistem sosial yang berkomitmen terhadap pengungkapan maksimum kebebasan kewarganegaraan individual dengan sebuah proses demokratis yang stabil dan tahan lama. Lebih khusus lagi, sekolah harus menyediakan informasi serta keterampilan bagi para siswa supaya mereka bisa belajar secara efektif bagi mereka sendiri. Sekolah harus mengajarkan bagaimana caranya menyelesaikan persoalan-persoalan praktis, melalui penerapan teknik-teknik pemecahan masalah secara individual maupun kelompok, yang didasarkan pada pembuktian pengetahuan secara ilmiah-rasional. Sekolah harus membantu para siswa untuk mengenali dan menanggapi kebutuhan bagi pembaharuan atau perombakan apa pun yang tampaknya merupakan tuntutan zaman. Tokoh-tokoh gerakan ini diwakili oleh Paulo Freire dan Neil Postman. ${ }^{12}$

Kedua, anarkisme pendidikan. Aliran ini menganggap bahwa individu secara deskriptif berada di bawah masyarakat (dalam arti psikologis atau developmental) karena individu ditentukan pada intinya oleh keanggotaan sosialnya. Di sisi lain, individu secara deskriptif lebih tinggi kedudukannya (superior) ketimbang masyarakat (dalam arti filosofis murni), dan ia menjadi benarbenar manusia serta mencapai perwujudan diri, hanya ketika ia melampaui perintah-perintah atau keharusan-keharusan (imperatif) masyarakat terorganisir itu secara menyeluruh.

Bagi kaum anarkis, pendidikan yang dipandang sebagai sebuah proses yang harus ada untuk belajar melalui pengalaman sosial alamiah manusia sendiri jangan sampai dikacaukan dengan kegiatan sekolah, yang hanya sebuah corak pendidikan, dan merupakan kaki tangan dari Negara otoriter. Akibat merosotnya tanggungjawab personal, Negara, dan sekolah membuat anak-anak menjadi tidak bisa dididik dalam arti pendidikan yang sejati, mereka seharusnya mendapatkan pendidikan sejati dan bukan hanya sekedar pelatihan. ${ }^{13}$

\footnotetext{
${ }^{12}$ Ibid., hlm. 466.

${ }^{13}$ Ibid., hlm. 482-488.
}

Ketiga, liberasionisme pendidikan. Aliran ini menekankan bahwa sasaran puncak pendidikan haruslah berupa penanaman pembangunan kembali masyarakat mengikuti alur yang benar-benar berkemanusiaan (humanistik), menekankan perkembangan sepenuhnya dari potensi-potensi khas setiap orang sebagai makhluk manusia. Ini hanya bisa berlangsung di dalam kerangka kerja sebuah sistem sosial yang berkomitmen terhadap pengungkapan maksimum kebebasan kewarganegaraan individual dengan sebuah proses demokratis yang stabil dan tahan lama. Lebih khusus lagi, sekolah harus menyediakan informasi serta keterampilan bagi para siswa supaya mereka bisa belajar secara efektif bagi mereka sendiri. Sekolah harus mengajarkan bagaimana caranya menyelesaikan persoalanpersoalan praktis, melalui penerapan teknikteknik pemecahan masalah secara individual maupun kelompok, yang didasarkan pada pembuktian pengetahuan secara ilmiah-rasional. Sekolah harus membantu para siswa untuk mengenali dan menanggapi kebutuhan bagi pembaharuan atau perombakan apa pun yang tampaknya merupakan tuntutan zaman. ${ }^{14}$

Ideologi merepresentasikan hadirnya imajinasi manusia tentang berbagai kenyataan dunia. Imajinasi tersebut memiliki eksistensi materialnya dalam bentuk praktek-praktek kehidupan. Praktek-praktek dimaksud memungkinkan terjadinya modifikasi dan reproduksi tatanan kehidupan; yang sesungguhnya juga menjadi wadah persemaian bagi ideologi itu sendiri. Ideologi bekerja dalam berbagai bentuk baik berupa pengetahuan, pencitraan, pemaknaan, dan juga penandaan; yang kesemuanya menciptakan efek mendalam bagi kehidupan manusia. Oleh sebab itu, ideologi senantiasa memuat apa yang disebut olehnya sebagai modus produksi dominan. Sebagian besar gerakan Islam yang muncul pada awal abad keduapuluh mendasarkan ideologinya pada Islam. Meskipun, secara budaya gerakangerakan Islam tersebut diperkaya oleh unsur

${ }^{14}$ Ibid., hlm. 466-471. 
lokal atau nasional yang pada akhirnya mencerminkan pandangan dan wawasan Islam yang beragam. Konstruksi pemahaman yang beragam tentang fenomena inilah yang merupakan substansi dari ideologi. Dengan demikian, konstruksi ideologi pendidikan Islam dari sebuah kelompok dapat dibaca dari bagaimana pandangan-pandangannya tentang manusia, alam, dan ilmu pengetahuan, yang kemudian dirumuskan dalam tujuan (visi misi) dan aktualisasinya dalam format pendidikan.

\section{Orientasi Ideologi Pendidikan Kuttab Al Fatih}

Kuttab Al Fatih Purwokerto adalah sebuah lembaga pendidikan Islam setingkat Sekolah Dasar yang terletak di Jl Kenanga Gang 10, Sumampir, Purwokerto Utara, Jawa Tengah. Lembaga ini didirikan pertama kali oleh Budi Ashari di kota Depok pada tahun 2012 dan dikembangkan ke beberapa kota besar, termasuk Purwokerto. Sebagaimana sekolah dan madrasah, secara struktural, lembaga ini dipimpin oleh seorang kepala kuttab. Dalam menjalankan roda organisasi, kepada kuttab dibantu oleh tim yang terdiri dari sekretaris, bendahara, penanggungjawab keilmuan (agama), dan guru-guru yang mengajar. Meskipun memiliki beberapa persamaan dengan sekolah dan madrasah, lembaga ini memilih untuk menggunakan istilah kuttab; sebuah istilah kelembagaan yang belum banyak dikenal oleh masyarakat. Sampai pada tahun 2017, jumlah pendaftar di kuttab Al Fatih Purwokerto selalu melebihi kuota.

Istilah kuttab bukan hanya tidak ada dalam nomenklatur perundang-undangan di Indonesia, namun juga tidak dikenal secara luas oleh masyarakat Indonesia. Kuttab merupakan sebuah lembaga pendidikan yang setara dengan sekolah atau madrasah di dalam sistem pendidikan nasional. Oleh sebab itu, sebelum mengkaji tentang kuttab Al Fatih Purwokerto, perlu penulis jelaskan secara sekilas tentang kuttab pada masa nabi yang menjadi ide dari pendirian kuttab Al Fatih yang embrionya bermula di kota Depok Jawa Barat ini.
Kuttab secara bahasa merupakan bentuk mufrad (tunggal) yang artinya tempat untuk belajar menulis. Adapun, bentuk jamaknya adalah kata ib. Kata kuttab sering salah dipahami sebagai bentuk jamak dari kata alkatib (penulis). Istilah kuttab sudah populer sebelum Islam sebagai tempat pendidikan dasar para siswa belajar bahasa, tulis menulis, dan syair. Menurut informasi dari Ahmad Syalabi, pada masa Islam muncul di kota Mekah, sudah ada 17 orang alumni kuttab yang dikenal sebagai orang yang bisa membaca dan menulis. ${ }^{15}$ Pada dakwah Islam, sistem pendidikan ala kuttab dilanjutkan sebagai salah satu tradisi dimana seorang guru mengajar Al-Qur`an kepada muridnya.

Pada era klasik, kuttab merupakan tempat pertama seorang anak belajar membaca Alquran, menulis, prinsip-prinsip agama, bahasa dan ilmu hitung. Kesenian menulis atau kaligrafi sangat diperhatikan pula karena merupakan bagian dari kesenian lukis-melukis. Di kuttab disediakan pengasuh-pengasuh khusus di bidang tesebut di atas secara penuh. Demikian pula, Rasulullah SAW. sendiri telah mempekerjakan orang-orang Islam (para sahabat) yang tahu tulis baca untuk mencatat ayat-ayat Alquran. Untuk mengajar kaum muslimin pun beliau meminta bantuan orang non-Muslim untuk mengajar kaum Muslimin membaca dan menulis karena pada masa itu jumlah kaum Muslimin yang pandai tulis baca masih sedikit. ${ }^{16}$

Keterampilan tulis baca - yang merupakan materi utama pendidikan kuttab - menjadi semakin penting sejalan dengan berkembangya komunitas Muslim Madinah. Kebutuhan paling penting, tentunya, adalah mencatat wahyu yang diterima oleh Nabi Muhammad saw. dari waktu ke waktu. Tetapi tulis-baca ini juga dibutuhkan untuk memungkinkan komunikasi antara umat Islam dengan suku-suku dan bangsa-bangsa lain. Tulis-baca sebagai sebuah prioritas penting

\footnotetext{
${ }^{15}$ Ahmad Syalaby, Sedjarah Pendidikan Islam, (Jakarta, Bulan Bintang, 1973), hlm.43.

${ }^{16}$ Muhammad Athiyah Al Abrosyi. Prinsip-Prinsip Dasar Pendidikan Islam. (Bandung: Pustaka Setia, 2003), hlm. 65 .
} 
Tabel 1. Perbandingan Kuttab, Madrasah, Pesantren

\begin{tabular}{|c|c|c|c|}
\hline Aspek & Madrasah & Pesantren & Kuttab \\
\hline Usia & $6-12$ tahun & Bebas & $5-12$ tahun \\
\hline Status lembaga & Formal & Non-formal & Non-formal \\
\hline Durasi pendidikan & 6 Tahun & Menyesuaikan kebutuhan & 7 Tahun \\
\hline Jenjang & $\begin{array}{l}\text { Dibagi menjadi kelas } 1,2 \text {, } \\
3,4,5 \text {, dan } 6 \text {. }\end{array}$ & Kondisional & $\begin{array}{l}\text { Dibagi menjadi } 2 \text { jenjang: kuttab } \\
\text { awal ( } 3 \text { tahun) dan kuttab qonuni } \\
\text { ( } 4 \text { tahun) }\end{array}$ \\
\hline Kurikulum & $\begin{array}{l}\text { Mengacu kepada kurikulum } \\
\text { agama Departemen Agama }\end{array}$ & $\begin{array}{l}\text { Berbasis pada kitab-kitab } \\
\text { klasik (kitab kuning) }\end{array}$ & Mengembangkan kurikulum mandiri \\
\hline Kualifikasi guru & Bergelar minimal sarjana & $\begin{array}{l}\text { Alumni pondok pesantren, } \\
\text { menguasi nahwu, sharaf, } \\
\text { dan kitab-kitab klasik. }\end{array}$ & $\begin{array}{l}\text { Memiliki kompetensi dalam Hafal } \\
\text { Qur`an, kesamaan dalam hal ideologi } \\
\text { keagamaan. }\end{array}$ \\
\hline
\end{tabular}

dapat dilihat dalam peristiwa pembebasan beberapa tawanan perang badar. ${ }^{17}$

Berangkat dari ide historis tersebut, maka Budi Ashari mengembangkan model pendidikan yang diklaim sebagai copy paste kuttab pada zaman nabi. Kehadiran kuttab Al Fatih sebagai sebuah lembaga pendidikan menyajikan sebuah model pendidikan alternatif di luar modelmodel yang telah ada; sekolah, madrasah, dan pesantren. Pendirian model pendidikan alternatif ini sekaligus merupakan kritik terhadap sistem pendidikan nasional yang ada saat ini yang dinilai tidak mampu melahirkan generasi yang baik. Ketidakmampuan sistem pendidikan yang ada dalam menjalankan fungsi pendidikan dibuktikan dengan maraknya degradasi moral di kalangan pemuda yang justru muncul dari lembaga pendidikan, terutama sekolah, yang seharusnya menjadi episentrum dari pendidikan moral itu sendiri. Ironi ini dianggap merupakan buah dari kegagalan sistem yang ada. Selain itu, nuansa kritik memang kerap mewarnai komentar para pendiri kuttab Al Fatih.

Budi Ashari pada tahun 2012 menggagas sebuah model pendidikan alternatif di luar sekolah. Alumni Fakultas Hadis Universitas Islam Madinah itu mengambil filosofi dari perkataan Malik Ibn Anas yang menyatakan bahwa "generasi akhir ummat ini tidak akan membaik, melainkan dengan mengikuti konsep dan metode yang menjadikan ummat terdahulu baik”. Dengan menggunakan filosofi ini, Budi

${ }^{17}$ Hasan Asari, Menyingkap Zaman Keemasan Islam (Bandung: Citapustaka Media, 2007), hlm. 25.
Ashari mengenalkan lembaga pendidikan yang disebut kuttab. Menurutnya, lembaga ini adalah lembaga yang sudah ada pada masa nabi, yang telah berhasil melahirkan generasi sahabat yang memiliki kapasitas luar biasa dalam berbagai macam bidang pada usia yang masih muda. Konsep kuttab, menurut kepala Kuttab Al Fatih Purwokerto, mengadopsi sistem kuttab yang pernah ada pada zaman pra Islam.

Kalau dulu pada zaman nabi, para sahabat, para salaf, umur 17 sudah bisa menjadi pemimpin seperti Usamah Ibn Zaid, umur 22 sudah bisa menjadi sultan seperti Muhammad Al Fatih, Imam Syafi i pada usia 15 sudah bisa menjadi mufti di Mekah, maka sangat jauh dari pemuda zaman sekarang. ${ }^{18}$

Inspirasi awal pendirian kuttab di kota Depok -yang kemudian dikembangkan di kota-kota lainnya, termasuk Purwokertoadalah untuk menghidupkan kembali tradisi lembaga pendidikan generasi awal. Hal ini lebih

\footnotetext{
${ }^{18}$ Wawancara dengan Kepala Kuttab Al Fatih Malang oleh Setyo Dwi Putranto. Setyo dalam skripsinya di UIN Malang meneliti tentang sistem pendidikan di Kuttab Al Fatih, Data observasi lapangan dari skripsi tersebut penulis ambil karena dirasa relevan dengan penelitian ini. Dinamika lapangan bisa saja berbeda antara kuttab Al Fatih di Purwokerto dan di Malang, akan tetapi landasan filosofis yang dikembangkan tetap sama karena berasal dari satu sumber, yaitu interpretasi pendidikan Budi Ashari selaku pendirinya. Lihat: Setyo Dwi Putranto, "Sistem Pendidikan Islam Model Kuttab: Studi Kasus di Kuttab Al Fatih Malang”, UIN Maulana Malik Ibrahim: Skripsi Sarjana, 2016), hlm. 64.
} 
ditegaskan lagi dengan fakta bahwa kurikulum yang diajarkan adalah kurikulum Al Quran yang diklaim persis dengan konsep kuttab pada zaman Islam awal. Bahkan, ada sebuah istilah untuk menyebut kurikulum kuttab ini sebagai "kurikulum abad satu", atau kurikulum yang diambil dari abad pertama hijriyah pada periode Islam awal.

Jadi, istilah kuttab - ditulis bergaris miring karena kata tersebut belum ada di dalam kamus besar bahasa Indonesia- dimunculkan sebagai pengganti istilah lembaga-lembaga pendidikan yang selama ini telah baku seperti sekolah, madrasah, dan pesantren. Kuttab bukanlah nama untuk sebuah institusi, akan tetapi institusi itu sendiri. Kuttab menawarkan sebuah sistem pendidikan yang sama sekali berbeda dengan lembaga-lembaga pendidikan lain. Siswa yang belajar di kuttab (5-12 tahun) tidak diperkenankan belajar di SD, karena kuttab memang menggantikan SD itu sendiri. Beberapa perbandingan untuk membedakan antara kuttab, madrasah, dan pesantren secara kelembagaan pada jenjang yang setara (pendidikan dasar) adalah seperti pada Tabel 1.

Kuttab Al Fatih didirikan pertama kali di kota Bogor pada tahun 2012. Pada saat pertamakali didirikan, kuota yang disediakan hanya 30 peserta didik. Akan tetapi ternyata jumlah pendaftar jauh melampaui kuota yang ditetapkan dan terus bertambah dari tahun ke tahun. Dalam rangka menampung animo masyarakat yang begitu besar, maka dibukalah cabang-cabang kuttab Al Fatih di beberapa kota di Indonesia. Sampai saat ini, tercatat ada 10 cabang kuttab Al Fatih sebagai berikut:

Berbeda dengan sekolah dasar (SD) yang menerapkan jenjang pendidikan 6 tahun, kuttab menerapkan jenjang pendidikan 7 tahun dengan pembagian berdasarkan usia. Setiap murid yang mendaftar ke kuttab akan dikelompokkan berdasarkan usia. Usia 5-7 tahun disebut sebagai kuttab awwal/ sedangkan usia antara 8-12 tahun disebut sebagai kuttab qonuni. Karena berada pada jalur non formal, ijasah dari kuttab tidak diakui oleh Negara. Akan tetapi, para alumni kuttab masih dimungkinkan untuk melanjutkan ke SMP dengan mengikuti program penyetaraan paket A.

Kurikulum yang diajarkan di kuttab berbeda dengan sekolah Islam pada umumnya. Kurikulum kuttab hanya mengajarkan ilmu Al Quran dengan orientasi iman. Mata pelajaran umum tidak diajarkan di kuttab. Akan tetapi, dalam pembelajaran iman, para guru berupaya mengintegrasikan ilmu pengetahuan dengan Al Quran. Dengan melihat kurikulum yang diajarkan pada kuttab, baik pada kelas awwal atau qonuni, dapat disimpulkan bahwa semua mata pelajaran yang diajarkan hanyalah mata pelajaran agama. Mata pelajaran umum hanya diberikan 30 menit sebelum selesai belajar. Akan tetapi, dalam pembelajaran keimanan, kurikulum agama tersebut diupayakan semaksimal mungkin untuk dijelaskan dengan pendekatan ilmu pengetahuan secara tematik.

Materi yang menjadi fokus kajian adalah juz 30. Misalnya ketika membahas surat al buruj, dimana ayat pertama berbicara tentang langit, maka guru menjelaskan kepada murid tentang langit dari kacamata ilmu fisika yang kemudian dikaitkan dengan keimanan. Demikian pula pada saat membahas tentang bumi, air, pohon-pohonan, dan lain sebagainya. Sebelum mulai bertugas, para guru kuttab sudah diberi pelatihan khusus tentang hal ini. Semua ilmu yang diajarkan di kuttab diklaim sebagai ilmu keagamaan. Akan tetapi ketika membahas tentang ayat-ayat tematik yang berbicara tentang alam semesta, maka ilmu tersebut diajarkan dengan kaca mata ilmu pengetahuan yang berkembang saat ini. Ilmu pengetahuan tidak disebut sebagai ilmu alam, namun ilmu keimanan. Konsep yang dikembangkan oleh kuttab Al Fatih adalah mengembangkan ilmu Al Quran. Sedangkan di dalam Al Quran sudah mencangkup berbagai informasi tentang ilmu pengetahuan kontemporer. Sehingga, semua ilmu pengetahuan yang berkembang disebut sebagai ilmu keimanan karena membuktikan kemukjizatan Al Quran.

Hal tersebut sesuai dengan visi dan misi yang dikembangkan oleh kuttab Al Fatih, dimana visinya adalah "melahirkan generasi 
gemilang di usia belia" yang dijabarkan dalam misi-misi sebagai berikut: 1 ) Pengajaran dan penanaman karakter iman; 2) Menghafal Al Quran; Menggali, meneliti, dan membuktikan kemukjizatan AlQuran; 3) Berbahasa peradaban; 4) Memiliki ketrampilan hidup.

Menurut data yang penulis dapat dari syu `un idari (bagian administrasi) di kuttab Al Fatih Purwokerto, perkembangan jumlah murid dari tahun ke tahun menunjukan sebuah peningkatan yang cukup pesat. Bahkan, pada setiap membuka penerimaan santri baru, antusias masyarakat cukup pesat. Pihak kuttab hanya membatasi penerimaan santri sejumlah 56 santri setiap tahun. Jumlah tersebut lebih kecil dibanding jumlah pendaftar yang jumlahnya lebih banyak. Yang penting untuk dikaji di sini adalah apa yang menjadi motif wali murid untuk memutuskan untuk menyekolahkan (baca:meng-kuttab-kan) putra putri mereka di $k u t t a b$ yang notebene hanya berstatus sebagai lembaga pendidikan non-formal yang tidak memiliki ijasah resmi dari pemerintah? Jika dikaitkan dengan fungsi pendidikan luar sekolah, maka kuttab Al Fatih menempatkan diri sebagai pengganti sekolah, bukan suplemen atau komplemen. Pendidikan luar sekolah yang memerankan fungsi pengganti sekolah yang berkembang saat ini, seperti pesantren kalong, biasanya diperuntukkan untuk siswa yang tidak mampu dalam ekonomi. Akan tetapi, wali murid yang mendaftarkan putranya di kuttab Al Fatih rata-rata dari kalangan kelas menengah, bukan dari kelas miskin. Biaya awal yang harus dibayarkan untuk masuk kuttab adalah 3 dinar atau setara dengan 6 juta rupiah. Adapun biaya bulanannya adalah 300 dirham atau setara dengan 400 ribu rupiah. Jumlah yang dapat dibilang cukup besar untuk ukuran lembaga pendidikan tingkat dasar. Dan angka tersebut relatif hanya dapat dijangkau oleh kalangan ekonomi menengah.

Selain itu, sistem yang ditawarkan oleh kuttab dianggap baru di Indonesia. Apa yang membuat wali murid tersebut "mengambil resiko" untuk memilih kuttab sebagai alternatif pendidikan? Selain itu, background keagamaan para wali murid juga relatif bervariasi, ada yang berasal dari kalangan NU, Muhammadiyah, PKS, dan lain-lain. Artinya tidak menunjukkan eksklusifitas kelompok aliran tertentu.

George Ritzer dan Douglas J. Goodman ${ }^{19}$ menjelaskan adanya dua hal yang menghambat seseorang untuk memiliki kebebasan memilih, yaitu pertama keterbatasan sumber daya dan kedua institusi sosial. Keterbatasan sumber daya, misalnya ekonomi, akan sangat membatasi kebebasan seseorang untuk memilih. Semakin sumber daya yang dimiliki, maka semakin sempit pula kebebasan memilihnya. Jika melihat kepada jumlah uang masuk yang harus dibayar pada awal masuk kuttab, yaitu 6 juta, maka dapat disimpulkan bahwa wali murid yang mendaftar adalah kelompok ekonomi menengah yang sebenarnya sangat mampu dan sangat bisa untuk memilih SD Islam favorit sebagai pendidikan untuk putra putrinya.

Sistem yang dikembangkan kuttab Al Fatih Purwokerto merupakan bentuk yang sama sekali baru dalam kamus pendidikan di Indonesia. Secara umum, ideologi yang dikembangkan oleh kuttab Al Fatih Purwokerto berhaluan romantistik, yaitu ingin membawa masa lalu ke masa kini.

Visi dari kuttab Al Fatih adalah "melahirkan generasi emas pada usia muda". Setidaknya ada dua hal yang penting untuk digali di sini, yaitu (1) tentang pengertian "generasi emas", dan (2) indikator "usia belia". Pada poin pertama, yang dimaksud dengan generasi emas adalah manusia yang memiliki pondasi iman yang kokoh, kemampuan agama yang baik, dan mampu menjalani hidup secara mandiri. Pendidikan di kuttab Al Fatih menekankan aspek keyakinan sebelum ilmu dan akhlak. Pada awal pembelajaran, para guru di kuttab Al Fatih selalu menekankan kepada para santri tentang keesaan Allah, bahwa Allah yang menciptakan alam semesta dan jagad raya yang luas ini. Paradigma yang dibangun

${ }^{19}$ George Ritzer dan Douglas J. Goodman, Teori Sosiologi: Dari Teori Sosiologi Klasik Sampai Perkembangan Mutakhir Teori Sosial Postmodern, (Yogyakarta: Kreasi Wacana, 2014), hlm. 448-449. 
Tabel 2. Orientasi Ideologi Kuttab Al Fatih

\begin{tabular}{|c|c|c|}
\hline Aspek & Filosofi & Kegiatan \\
\hline $\begin{array}{l}\text { Basic Value: interpretasi } \\
\text { terhadap wahyu dan kitab } \\
\text { suci agama }\end{array}$ & $\begin{array}{l}\text { Mengambil ide, khususnya dari perkaaan Malik Ibn } \\
\text { Hanbal bahwa generasi akhir tidak akan berhasil } \\
\text { maju seperti pendahulunya, kecuali dengan mengikuti } \\
\text { metode dan strategi yang sama }\end{array}$ & 0 \\
\hline $\begin{array}{l}\text { Visi : Melahirkan generasi } \\
\text { emas di usia belia }\end{array}$ & $\begin{array}{l}\text { Mengambil ide dari sejarah periode awal, seperti } \\
\text { Usamah Ibn Zaid yang bisa menjadi panglima perang } \\
\text { di usia } 18 \text { tahun }\end{array}$ & - \\
\hline $\begin{array}{l}\text { Misi: 1. pengajaran dan } \\
\text { penanaman karakter Iman. }\end{array}$ & $\begin{array}{l}\text { Mengambil ide dari hadis nabi yang mengatakan } \\
\text { bahwa iman harus diajarkan sebelum ilmu dan } \mathrm{Al} \\
\text { Quran }\end{array}$ & Tadabbur alam \\
\hline $\begin{array}{l}\text { Misi 2: meneliti } \\
\text { dan membuktikan } \\
\text { kemukjizatan Al-Qur’an }\end{array}$ & $\begin{array}{l}\text { Mengambil ide dari sejarah periode awal, dimana } \\
\text { para sahabat mengimani terlebih dahulu wahyu, baru } \\
\text { kemudian ilmu yang berkembang membuktikan } \\
\text { kebenaran wahyu tesebut }\end{array}$ & $\begin{array}{l}\text { Mufaraqat (pelajaran umu } \\
\text { yang relevan) }\end{array}$ \\
\hline $\begin{array}{l}\text { Misi 3: Menghafal Al } \\
\text { Quran }\end{array}$ & $\begin{array}{l}\text { Mengambil ide dari sejarah periode awal, dimana } \\
\text { para sahabat dan ilmuwan muslim seperti Ibnu Sina } \\
\text { sudah hafal Al Quran sejak usia dini }\end{array}$ & Talaqqi Al Quran \\
\hline $\begin{array}{l}\text { Misi 4: berbahasa } \\
\text { peradaban }\end{array}$ & $\begin{array}{l}\text { Mengambil ide dari sejarah periode awal, dimana } \\
\text { bahasa Arab menjadi bahasa ilmu pengetahuan }\end{array}$ & Pembiasaan berbahasa Arab \\
\hline $\begin{array}{l}\text { Misi 5: memiliki } \\
\text { ketrampilan hidup }\end{array}$ & $\begin{array}{l}\text { Mengambil ide dari searah periode awal, dimana } \\
\text { sahabat sudah mandiri di usia muda. Misalnya Ibnu } \\
\text { Umar yang pada usia } 17 \text { tahun sudah mandiri }\end{array}$ & Memanah, Berenang \\
\hline
\end{tabular}

adalah merujuk pada zaman nabi, dimana pada saat itu pembelajaran nabi hanya tentang iman saja. Nabi tidak mengajarkan tentang apa yang saat ini disebut sebagai ilmu pengetahuan. Toh begitu, produk dari pendidikan model seperti itu dapat melahirkan ahli dalam berbagai macam bidang.

Adapun, yang dimaksud dengan "usia belia" adalah usia sekitar 12-15 tahun, yaitu ketika seorang anak sudah mukallaf atau baligh. Dasar pembagian usia ini didasarkan pada fikih, sebagai berikut:
12-15 tahun
Baligh
7-12 tahun
Tamyiz (anak-anak)
3- 6 tahun Hadhonah (masa balita)
0- 2 tahun
Rodho 'ah (masa susuan)

Visi tersebut kemudian diturunkan menjadi empat misi, yaitu: pertama, pengajaran dan penanaman karakter Iman. Paradigma yang dibangun dari misi ini berangkat dari hadis nabi yang menyatakan bahwa iman harus diprioritaskan dari belajar Al-Qur'an. Iman kepada Allah secara uluhiyah dan rububiyyah menjadi pondasi paling penting yang harus ditanamkan kepada anak sebelum memulai untuk belajar ilmu-ilmu. Kedua, meneliti dan membuktikan kemukjizatan Al-Qur'an. Materi yang menjadi kurikulum di kuttab Al Fatih Purwokerto adalah Al-Qur'an juz 30, dimana ayat-ayat dan surah di dalam juz tersebut banyak yang menyinggung alam semesta. Di sini, kuttab Al Fatih menganggap bahwa belajar ilmu fisika harus dimulai dari belajar ayat Al-Qur'an, sebagaimana yang dilaksanakan oleh nabi pada tempo dulu. Ketiga, berbahasa peradaban. Yang dimaksud dengan bahasa peradaban adalah bahasa Arab, bahasa yang digunakan oleh Al-Qur'an, yang menjadi bahasa ilmu pengetahuan pada masa keemasan Islam, khususnya pada zaman Abbasiyah. Keempat, memiliki ketrampilan hidup. Budi Ashari memandang bahwa pada zaman nabi pendidikan tidak dilaksanakan dengan interval waktu yang sangat panjang, sebagaimana saat ini. Pada masa nabi, ketika seseorang sudah masuk masa balligh, maka dia sudah dianggap dewasa dan bisa mencari nafkah sendiri.

Jika menggunakan kaca mata O'neil, dapat dikatakan bahwa orientasi ideologi di kuttab 
Al Fatih adalah konservatif-fundamentalisreligius. Dimana tujuan puncak pendidikan adalah untuk mematuhi kehendak Allah sebagaimana diwahyukan di dalam kitab suci agama. ${ }^{20}$ Orientasi ideologi di kuttab Al Fatih juga berhaluan romantistik, ingin menghadirkan "masa lalu" ke masa depan. Interpretasi-interpretasi dari wahyu dan hadis yang dilakukan oleh kuttab Al Fatih sangat bergantung pada penafsiran pendirinya, Budi Ashari. Di sini, sikap konservatif tersebut tampak dari upayanya mengambil bentuk, bukan substansi, dari sebuah informasi yang bersifat historis. Jika menggunakan pemetaan Djawad Ridha, maka orientasi ideologi kuttab Al Fatih bercorak konservatif (al-muhafidz), dimana ideologi ini bergumul pada persoalan pendidikan yang cenderung bersikap murni keagamaan.

Dalam mengembangkan kurikulum pendidikannya, nuansa kritik terhadap ideologi Barat sangat terasa di kuttab Al Fatih. Dari sini dapat dipahami mengapa lembaga ini mengambil bentuk yang berbeda dengan sekolah yang merupakan produk dari peradaban Barat. Menurut Mukhtaruddin, ideologi konservatif cenderung membuat analogi-analogi di luar nalar, dan cenderung mengambil sikap antitesis dari apapun yang bernuansa Barat. $^{21}$

Kurikulum yang diajarkan di kuttab berbeda dengan sekolah Islam pada umumnya. Kurikulum kuttab hanya mengajarkan ilmu Al Quran dengan orientasi iman. Mata pelajaran umum tidak diajarkan di kuttab. Akan tetapi, dalam pembelajaran iman, para guru berupaya mengintegrasikan ilmu pengetahuan dengan Al Quran. Dengan melihat kurikulum yang diajarkan pada kuttab, baik pada kelas awwal atau qonuni, dapat disimpulkan bahwa semua mata pelajaran yang diajarkan hanyalah mata pelajaran agama. Mata pelajaran umum hanya diberikan 30 menit sebelum selesai belajar. Akan tetapi, dalam pembelajaran keimanan, 247.

${ }^{20}$ William F O`neil, Ideologi-ideologi, hlm.187-

${ }^{21}$ Mukhtaruddin, "Ideologi Pendidikan Islam Garis Keras”, Jurnal Suluh Vol 2No 1 Januari-April 2009, 129. kurikulum agama tersebut diupayakan semaksimal mungkin untuk dijelaskan dengan pendekatan ilmu pengetahuan secara tematik. Materi yang menjadi fokus kajian adalah juz 30. Misalnya ketika membahas surat al buruj, dimana ayat pertama berbicara tentang langit, maka guru menjelaskan kepada murid tentang langit dari kacamata ilmu fisika yang kemudian dikaitkan dengan keimanan. Demikian pula pada saat membahas tentang bumi, air, pohonpohonan, dan lain sebagainya. Sebelum mulai bertugas, para guru kuttab sudah diberi pelatihan khusus tentang hal ini.

Kurikulum yang dikembangkan yang di kuttab Al Fatih merupakan kurikulum agama murni yang berhaluan konservatiffundamentalis-religius. Bukan berarti ilmu pengetahuan umum tidak diajarkan di lembaga ini. Ilmu pengetahuan umum diajarkan sebagai penguat untuk "membuktikan kemukjizatan AlQuran". Dimensi keimanan lebih diorientasikan daripada pembuktian iman itu sendiri. Ilmu umum yang dipelajari di kuttab Al Fatih hanya yang dianggap relevan dengan tema-tema yang terkandung di dalam Al-Qur`an, khususnya juz 30. Misalnya, pada saat membahas tentang alam semesta, konstruksi yang dikembangkan adalah meyakini konsep alam semesta yang sudah ada di dalam Al-Quran, kemudian membuktikan keyakinan tersebut dengan ilmu pengetahuan yang berkembang yang dianggap sesuai dengan keyakinan tersebut.

\section{KESIMPULAN}

Iklim reformasi yang mengakomoadasi kebebasan berpendapat dan berekspresi membuka ruang bagi lahirnya berbagai macam varian ideologi, termasuk di dalam dunia pendidikan. Pertumbuhan lembagalembaga pendidikan paska reformasi cenderung bernuansa agama. Hal ini dilihat dari begitu dominannya kemunculan sekolah-sekolah dengan label Islam, termasuk lembaga pendidikan non sekolah - kuttab- yang menjadi kajian dalam makalah ini.

Kuttab Al Fatih Purwokerto merupakan lembaga pendidikan Islam lahir di tengah 
iklim keterbukaan reformasi. Pendiriaan lembaga ini lahir dari sebuah kritik terhadap implementasi pendidikan saat ini yang dinilai gagal dalam melahirkan generasi emas. Kritik tersebut kemudian dituangkan dalam pendirian sebuah lembaga pendidikan yang berhaluan romantistik, yaitu mengembangkan model pendidikan dengan berbasis pada kebijaksanaan masa klasik yang dinilai telah sukses melahirkan apa yang disebut sebagai "generasi emas". Jika menggunakan kaca mata O'neil, dapat dikatakan bahwa orientasi ideologi pendidikan di kuttab Al Fatih adalah konservatif-fundamentalisreligius. Kuttab Al Fatih merupakan model lembaga pendidikan yang merekonstruksi kurikulum lama (pada zaman keemasan Islam klasik) dengan tujuan melahirkan output yang mirip dengan generasi Islam masa lalu. $* * *$

\section{DAFTAR PUSTAKA}

Achmadi, Ideologi Pendidikan Islam Paradigma Humanisme Teosentris. Yogyakarta: Pustaka Pelajar, 2010.

Azyumardi Azra, Pergolakan Politik Islam dari fundamentalisme, modernism, hingga post modernism, Jakarta: Paramadina, 1996.

Berger, Peter L. dan Thomas Luckmann, Tafsir Sosial atas Kenyataan: Risalah tentang Sosiologi Pengetahuan, Jakarta: LP3ES, 1990.
Haedar Nashir, "Gerakan Islam Syari’at Reproduksi Ideologis di Indonesia", Yogyakarta: Disertasi Universitas Gadjah Mada, 2010.

Noorhaidi Hasan, Laskar Jihad: Islam, Militansi, dan Pencarian Identitas di Indonesia PascaOrde Baru, Jakarta: LP3ES, 2008.

O`neil, William F, Ideologi-ideologi Pendidikan, Yogyakarta: Pustaka Pelajar, 2008.

Ritzer, George dan Goodman, Douglas J., Teori Sosiologi: Dari Teori Sosiologi Klasik Sampai Perkembangan Mutakhir Teori Sosial Postmodern, Yogyakarta: Kreasi Wacana, 2014.

Setyo Dwi Putranto, "Sistem Pendidikan Islam Model Kuttab: Studi Kasus di Kuttab Al Fatih Malang", UIN Maulana Malik Ibrahim: Skripsi Sarjana, 2016..

Suyatno, "Sekolah Islam Terpadu: Gnealogi, Ideologi, dan Sistem Pendidikan", Yogyakarta, Disertasi UIN Sunan Kalijaga, 2013.

Syalaby, Ahmad, Sedjarah Pendidikan Islam, Jakarta, Bulan Bintang, 1973.

Yudi Latif, Dialektika Islam: Tafsir Sosiologis atas Sekularisasi dan Islamisasi di Indonesia, Yogyakarta: Jalansutra, 2007.

Zuly Qodir, Gerakan Sosial Islam: Manifesto Kaum Beriman, Yogyakarta: Pustaka Pelajar, 2009. 